\title{
REFORMA DA PREVIDÊNCIA: A QUEM INTERESSA?
}

\section{SOCIAL SECURITY REFORM: WHO INTERESTS?}

\author{
Flavia Emilia Silva de Oliveira ${ }^{i}$ \\ Lindinei Rocha Silvail \\ Hilton Neves Filhoill
}

Resumo: Este artigo tem o objetivo de apresentar uma reflexão sobre um fato contemporâneo que tem causado grandes debates no Brasil: a Reforma da Previdência Social. Proposta no Congresso Nacional pelo Presidente da República, sob o pano de fundo da transição da presidência do País, após o impeachment, o projeto tem sido anunciado como o carro chefe da gestão do Poder Executivo. Para discutir os limites possíveis da proposta de Reforma da Previdência Social, servir-nos-emos da Constituição Federal de 1988 e, sobretudo, das declarações e intenções escusas da proposta amplamente divulgadas e apoiadas pelas mídias do País. Um dos conceitos norteadores de nossa análise baseia-se na premissa do pedagogo Paulo Freire ao defender que a leitura crítica do mundo precede a leitura da palavra. Desta forma, é preciso ir além das palavras, ter uma visão crítica do mundo que subsidie sua interpretação. As discussões e reflexões deste artigo buscam fomentar o debate sobre um tópico que diz respeito a todo cidadão brasileiro, afetando-o indelevelmente no presente e no futuro, assim como repensar o papel preponderante do acesso à informação, questionando as intenções e os meios de divulgação midiático.

\footnotetext{
i Mestre em Desenvolvimento Local pelo Centro Universitário Augusto Motta (UNISUAM). Possui especialização em Direito Previdenciário pela Escola Superior Verbo Jurídico (ESVJ) e Graduada em Direito pela Universidade Iguaçu (UNIG).

ii Doutor em Letras Neolatinas pela Universidade Federal do Rio de Janeiro; Mestre em Língua Espanhola e Literaturas Hispânicas - UFRJ. Bacharel e Licenciado em Letras (Português-Espanhol) UFRJ. Bacharel em Direito. Atualmente é Coordenador de Extensão, do NAPNE e professor no IFRJ.

iii Pós Graduado em Direito Civil e Processo Civil pela UNIG - Universidade Iguaçu. Pós Graduado em Psicologia Jurídica pela Universidade Estácio de Sá. Mestre em Desenvolvimento Local pelo Centro Universitário Augusto Motta - UNISUAM
} 
Palavras-chave: Cidadania. Justiça Social. Reforma da Previdência. Previdência Social.

Abstract: This article aims to present a reflection on a contemporary fact that has caused great debates in Brazil: the Social Security Reform. Proposed in the National Congress by the President of the Republic, under the backdrop of the transition of the presidency of the country, after the impeachment, the project has been announced as the flagship of the executive branch management. In order to discuss the possible limits of the Social Security Reform proposal, we will use the Federal Constitution of 1988 and, above all, the statements and intentions of the proposal, widely disseminated and supported by the country's media. One of the guiding concepts of our analysis is based on the pedagogue Paulo Freire's premise in arguing that the critical reading of the world precedes the reading of the word. In this way, it is necessary to go beyond words, to have a critical view of the world that subsidizes their interpretation. The discussions and reflections of this article seek to foment the debate on a topic that concerns every Brazilian citizen, affecting it indelibly in the present and in the future, as well as rethinking the preponderant role of access to information, questioning the intentions and means of disclosure media.

Keywords: Citizenship, Social Justice, Social Security Reform, Social Security

\title{
1 INTRODUÇÃO
}

\begin{abstract}
"O pior analfabeto é o analfabeto político. Ele não ouve, não fala, nem participa dos acontecimentos políticos. [...] Não sabe o imbecil que, da sua ignorância política, nasce a prostituta, o menor abandonado e o pior de todos os bandidos, que é o político vigarista, pilantra, corrupto e lacaio das empresas nacionais e multinacionais."

(Bertolt Brecht)
\end{abstract}

Há uma máxima atribuída a Monteiro Lobato no que diz respeito ao êxito de uma nação: "um país se faz com homens e livros". Infelizmente, nossa realidade nacional nos mostra que boa parte da população tem acesso precário à educação, vista por muitos, inclusive, como um luxo para as camadas menos favorecidas da sociedade. Se são raros os leitores e os livros no País, o que dizer dos homens? Nesse caso, nem cabe à po- 
liticamente correta substituição de "homem" por "humanidade", porque são os do gênero masculino a maioria esmagadora que conduz o País, e não parecem fazer jus aos homens a que se referia Monteiro Lobato, pelo contrário, ratificam outra mazela nacional, a falta de representatividade da população no cenário político.

Obviamente, não é possível em um artigo discutirmos tamanho desmando no País, por isso, deter-nos-emos na controvertida proposta de Reforma da Previdência apresentada pelo governo Michel Temer ao Congresso Nacional. Analisaremos tal tema à luz do conceito de leitura crítica do mundo de Paulo Freire (1985), dando relevo a vozes destoantes do discurso midiático apresentado nos telejornais da TV. A complexidade da proposta do Governo e o exíguo espaço de um artigo nos levam a restringir nossa análise ao questionamento de algumas informações amplamente divulgadas na grande mídia como axiomas. Vamos trazer à tona o comentário de especialistas no assunto e elaborar algumas considerações sobre o tema.

\section{REFORMA DA PREVIDÊNCIA PROPOSTA PELO GOVERNO FEDERAL}

Tema de suma importância na atualidade é a Reforma da Previdência pretendida pelo Governo Federal, que não mede esforços para sua aprovação e retira do trabalhador direitos sociais duramente conquistados e garantidos pela Constituição Federal.

Não se pode olvidar da pretensa reforma da Previdência pelo Governo Federal que, data maxima venia, lascera o Direito Previdenciário construído e historicamente embasado nos direitos sociais lutados e conquistados.

A Previdência Social é fruto de uma intensa luta dos trabalhadores. Para Mano (2016) a Previdência Social representa uma perspectiva de solidariedade intergeracional e de capacidade para o trabalho, já que aqueles(as) inseridos no mercado contribuem diretamente para a proteção social, para diversos riscos sociais, dentre eles dos que perderam temporária ou permanentemente a sua capacidade laborativa.

De acordo com o renomado constitucionalista José Afonso da Silva, "direitos sociais são prestações positivas proporcionadas pelo Estado, direta ou indiretamente, que possibilitam melhores condições de vida aos 
mais fracos, direitos que tendem a realizar a igualização de situações sociais desiguais" (SILVA, 2012, p. 286).

O direito à Seguridade Social é um direito de luta por séculos, com a missão de pavimentar o caminho para o futuro. Vianna faz menção a um provérbio chinês que diz que "os inteligentes aprendem com os próprios erros, os sábios aprendem com os erros dos outros e os burros nunca aprendem" (SILVA, 2012. p. 3) para explicitar que a evolução histórica de qualquer instituto do Direito não é mera formalidade de qualquer assunto, mas o caminho necessário para a compreensão do objeto sob todos os ângulos.

O Direito Previdenciário, tal como o Direito Ambiental, é dotado de alto teor de humanismo e universalidade, não se destinando à proteção dos interesses de um indivíduo, mas dos mais necessitados dentre o gênero humano (BONAVIDES, 2007, p. 569). A solidariedade se correlaciona com os direitos essenciais, afigurando-se como fecundação a responsabilidade de cada membro da sociedade em prol de todos.

Assim, o Direito assume um novo papel de mediador do agir humano na busca do equilíbrio e da integridade do planeta, implorando por um olhar sobre o outro, o humano (SILVA, 2011).

O Estado deve ser partícipe do princípio constitucional da solidariedade, no que diz respeito à garantia das aposentadorias e benefícios previdenciários, para além da materialização do direito à sobrevivência dos trabalhadores. No entanto, a Previdência torna-se uma grande fonte de arrecadação administrada pelo Estado e, nesse sentido, os seus recursos se constituem como objeto de disputa política e econômica.

\subsection{Argumentos do Governo Federal para a Reforma}

O discurso recorrente da necessidade de contenção dos gastos com a Previdência começa a ser deflagrado a partir da década de 40, mas ganha mais força nos anos 80, mediante os altos índices de desemprego, inflação e crise econômica (AMARO; MENEGUIN, 2003). Os argumentos de comprovação do déficit previdenciário estavam circunscritos em enveIhecimento populacional: descompasso entre arrecadação e despesas, entre trabalhadores ativos e inativos, principalmente devido ao desemprego e aumento da expectativa de vida (CASTOR, 1999). 
Sobressai desse contexto o discurso da inviabilidade de manter a política previdenciária nos mesmos moldes e necessidade de operar uma "reforma". Segundo Wagner, Rambo e Andrade (2017), o Governo Federal está tentando, mais uma vez, mudar as regras de aposentadoria e pensão para os trabalhadores da iniciativa privada e para os servidores públicos, excluindo da proposta de alteração, apenas, os policiais, bombeiros militares e os militares das Forças Armadas.

Com esse objetivo, apresentou ao Congresso Nacional, em 05/12/2016, a Proposta de Emenda Constitucional nº 287 (PEC 287/2016), que, para entrar em vigor, deverá ser aprovada na Câmara dos Deputados e no Senado Federal (Congresso Nacional), com maioria de três quintos dos membros da Casa do Congresso, na forma do art. $60, \S 2^{\circ}$, da CF (SILVA, 2012, p. 527). O argumento utilizado é o de que a Reforma é imprescindível para evitar a "quebra" do sistema previdenciário, afirmando o Governo Federal que há déficit da Previdência, ou seja, que os valores gastos com aposentadorias e pensões seriam maiores que os valores arrecadados para cobrir essas despesas.

\subsection{A Seguridade Social é estruturalmente superavitária}

Estudos feitos pela Associação Nacional dos Auditores Fiscais da Receita Federal do Brasil (ANFIP) mostram uma situação bem diferente. Eles revelam que o tal déficit não existe, mas decorre da forma de cálculo utilizada pelo Governo para contabilizar as receitas e despesas da Previdência (WAGNER; RAMBO; ANDRADE, 2017).

A Constituição Federal estabeleceu um conjunto integrado de ações de iniciativa dos poderes públicos e da sociedade, Seguridade Social, destinados a assegurar direitos relativos: à saúde (para todos), à assistência social (para quem precisa) e à Previdência Social (que abrange o pagamento de aposentadorias, pensões e demais benefícios previdenciários) (SILVA, 2012, p. 830). Para financiar a Seguridade Social, em seu artigo 195, a Constituição Federal estabeleceu diversas fontes de recursos: contribuição previdenciária paga pelos trabalhadores e empresas, COFINS, Contribuição Social sobre o Lucro Líquido (CSLL), PIS/ PASEP, recursos do próprio orçamento da União, Estados, Municípios e Distrito Federal etc. 
Desse modo, todos esses recursos devem financiar

"a Seguridade Social como um todo (saúde, assistência social e Previdência Social). E ele tem sido mais do que suficiente para isso: só no ano de 2014, por exemplo, já descontadas as despesas com as três áreas da Seguridade Social, sobraram mais de $R \$ 54$ bilhões. Em 2015, a sobra foi de mais de $R \$ 11$ bilhões e 200 milhões. Ou seja, não está faltando dinheiro para sustentar a Previdência Social! (WAGNER; RAMBO; ANDRADE, 2017, p. 6, grifo do autor).

Considerando-se as receitas e as despesas de 2016, $\mathrm{R} \$$ 718,9 bilhões e de $\mathrm{R} \$ 776,0$ bilhões, respectivamente, percebe-se que a Seguridade Social apresentou um resultado negativo de $R \$ 57,0$ bilhões nesse ano. O acompanhamento das receitas e das despesas nos últimos 12 anos permite identificar os números de 2016 como resultantes de fatores conjunturais. De 2005 a 2016, os números da Seguridade Social produziram, em média, $R \$ 50,2$ bilhões de superávit anuais, mesmo considerando o resultado negativo de 2016 - único da série (ASSOCIAÇÃO NACIONAL DOS AUDITORES-FISCAIS DA RECEITA FEDERAL DO BRASIL, 2017, p. 53).

Corroborando com os dados da ANFIP, concluiu a Comissão Parlamentar de Inquérito (CPI) da Previdência, sob a presidência do Senador Federal Paulo Paim (PT-RS), sendo aprovado, por unanimidade, o relatório final do senador Hélio José (Pros-DF), que a Previdência é superavitária, além de sugerir projetos de lei e emendas à Constituição para aperfeiçoar a legislação e a solicitação de algumas providências do Governo Federal (AGÊNCIA SENADO, 2017a), conforme principais pontos do relatório (AGÊNCIA SENADO, 2017b):

Quadro 1 - Principais pontos do relatório da CPI da Previdência

\begin{tabular}{|l|l|}
\hline \multicolumn{2}{|c|}{ Principais pontos do relatório da CPI da Previdência } \\
\hline $\begin{array}{l}\text { Estimati- } \\
\text { vas falhaslemas apresentados }\end{array}$ & $\begin{array}{l}\text { Estimativas que serviram de base para a proposta de reforma em } \\
\text { tramitação no Congresso têm erros e imprecisões. Tomou como } \\
\text { base um ano de forte recessão e parâmetros irrealistas, delinean- } \\
\text { do um futuro caótico. }\end{array}$ \\
\hline
\end{tabular}




\begin{tabular}{|c|c|}
\hline Fraudes & $\begin{array}{l}\text { A gestão para concessão e manutenção de benefícios está sujeita } \\
\text { a fraudes e erros que impactam negativamente as contas. Na } \\
\text { maioria dos casos, os crimes não são praticados por segurados } \\
\text { comuns, mas por quadrilhas especializadas. }\end{array}$ \\
\hline $\begin{array}{l}\text { Desvios } \\
\text { de recur- } \\
\text { sos }\end{array}$ & $\begin{array}{l}\text { Historicamente os recursos previdenciários sofreram significativas } \\
\text { apropriações por parte da União, resultando na destinação de } \\
\text { dinheiro para outros gastos de interesse do Governo. }\end{array}$ \\
\hline DRU & $\begin{array}{l}\text { Com a criação da DRU (Desvinculação de Receitas da União), uma } \\
\text { parcela significativa dos recursos originalmente destinados ao } \\
\text { financiamento da Previdência foi redirecionada. }\end{array}$ \\
\hline $\begin{array}{l}\text { Empresas } \\
\text { públicas }\end{array}$ & $\begin{array}{l}\text { Além do setor privado, as empresas públicas também têm acú- } \\
\text { mulo de débitos previdenciários que impactam o sistema. }\end{array}$ \\
\hline Leniência & $\begin{array}{l}\text { O Estado Brasileiro é leniente com as empresas devedoras, as } \\
\text { quais, por sua vez, beneficiam-se de uma legislação permissiva. }\end{array}$ \\
\hline Isenções & $\begin{array}{l}\text { Há de parte do Governo uma recorrente prática de criação de } \\
\text { mecanismos de isenção fiscal e parafiscal para empresas e enti- } \\
\text { dades diversas, algo que também tem contribuído negativamente } \\
\text { para as contas do setor. }\end{array}$ \\
\hline Refis & $\begin{array}{l}\text { O parcelamento e o perdão de multas, de juros, de correção mo- } \\
\text { netária e de encargos legais tornaram-se algo recorrente, mesmo } \\
\text { em períodos de prosperidade econômica, e esta prática tem se } \\
\text { tornado uma constante, com prejuízo da Seguridade Social. }\end{array}$ \\
\hline $\begin{array}{l}\text { Diferença } \\
\text { de trata- } \\
\text { mentos }\end{array}$ & $\begin{array}{l}\text { A legislação, que é generosa em conceder o perdão de dívidas } \\
\text { e oferecer parcelamentos benevolentes aos sonegadores da } \\
\text { seguridade, não pode ser rigorosa com o corte da despesa de } \\
\text { benefícios dos miseráveis e dos trabalhadores, aposentados e } \\
\text { pensionistas. }\end{array}$ \\
\hline $\begin{array}{l}\text { Envelhe- } \\
\text { cimento } \\
\text { da popu- } \\
\text { lação }\end{array}$ & $\begin{array}{l}\text { As projeções do Governo levam em conta um envelhecimento } \\
\text { exagerado da população, ao passo que consideram o crescimen- } \\
\text { to do PIB muito abaixo da média histórica nacional. Tais falhas } \\
\text { exacerbam a previsão futura de necessidade de financiamento do } \\
\text { RGPS (Regime Geral de Previdência Social). }\end{array}$ \\
\hline \multicolumn{2}{|r|}{ Soluções propostas } \\
\hline $\begin{array}{l}\text { Políticas } \\
\text { de deso- } \\
\text { nerações }\end{array}$ & $\begin{array}{l}\text { O Governo tem que reavaliar toda a política de desonerações e } \\
\text { de renúncias fiscais, de tal forma que a contribuição equitativa } \\
\text { de todos os segmentos econômicos impacte positivamente no } \\
\text { resultado da arrecadação. }\end{array}$ \\
\hline $\begin{array}{l}\text { Apoio às } \\
\text { carreiras }\end{array}$ & $\begin{array}{l}\text { A Administração Pública Federal precisa apoiar as estruturas de } \\
\text { arrecadação, cobrança da dívida ativa, e de prestação de serviços } \\
\text { aos segurados do RGPS. Deve ainda ampliar os quantitativos de } \\
\text { auditores fiscais dedicados à arrecadação da Seguridade Social. }\end{array}$ \\
\hline
\end{tabular}




\begin{tabular}{|l|l|}
\hline $\begin{array}{l}\text { Tecnolo- } \\
\text { gia }\end{array}$ & $\begin{array}{l}\text { O Poder Executivo deve intensificar o uso das tecnologias de } \\
\text { informação e Inteligência na fiscalização tributária, de forma a } \\
\text { aumentar a produtividade e eficiência do Fisco. }\end{array}$ \\
\hline $\begin{array}{l}\text { Legisla- } \\
\text { ção }\end{array}$ & $\begin{array}{l}\text { É necessária a urgente modernização da legislação que rege a } \\
\text { execução fiscal. Desde 2009, tramita no Congresso o PL } 5080 \text { com } \\
\text { essa finalidade. O Executivo deve requerer a urgência constitucio- } \\
\text { nal para a tramitação da proposta, que está parada na Câmara. }\end{array}$ \\
\hline Mutirão & $\begin{array}{l}\text { O TCU, o Ministério da Fazenda e a Receita Federal devem em } \\
\text { caráter emergencial reforçar suas estruturas e promover muti- } \\
\text { rões para o julgamento de todos os recursos administrativos que } \\
\text { envolvam contribuições sociais até o fim do ano de 2018. }\end{array}$ \\
\hline $\begin{array}{l}\text { Combate } \\
\text { a fraudes }\end{array}$ & $\begin{array}{l}\text { É recomendável a adoção de estratégia permanente e integrada } \\
\text { de combate às fraudes e crimes contra a Previdência, nos moldes } \\
\text { da Estratégia Nacional de Combate à Corrupção e à Lavagem } \\
\text { de Dinheiro (ENCCLA), assim como a adoção de mecanismos de } \\
\text { verificação e revisão periódica de benefícios. }\end{array}$ \\
\hline $\begin{array}{l}\text { Extinção } \\
\text { do Refis }\end{array}$ & $\begin{array}{l}\text { A política de concessão de parcelamento de dívidas (Refis) deve } \\
\text { ser revista. Na atual concepção, virou prática perniciosa e passou } \\
\text { a representar um estímulo à sonegação e à livre concorrência, ao } \\
\text { deixar os contribuintes adimplentes em desvantagem. }\end{array}$ \\
\hline $\begin{array}{l}\text { Propostas } \\
\text { legislati- } \\
\text { vas }\end{array}$ & $\begin{array}{l}\text { A CPI elaborou dois projetos de lei e três propostas de emenda à } \\
\text { Constituição que vão viabilizar algumas das sugestões apresen- } \\
\text { tadas. Por não dependerem da iniciativa do chefe do Executivo, } \\
\text { podem começar a tramitar de imediato. }\end{array}$ \\
\hline
\end{tabular}

Agência Senado (Reprodução autorizada mediante citação da Agência Senado)

Fonte: (AGÊNCIA SENADO, 2017b).

Os resultados da Seguridade Social sempre foram superavitários, e suas receitas sempre superaram as despesas. A insistência em renovar periodicamente as desvinculações de Receitas da União focadas nas contribuições sociais é uma prova cabal. (ASSOCIAÇÃO NACIONAL DOS AUDITORES FISCAIS DA RECEITA FEDERAL DO BRASIL, 2017).

"Apesar de o resultado ter sido negativo em 2016, a Seguridade é estruturalmente superavitária. Os números variam ano a ano. As receitas crescem mais ou menos em resposta à economia. As despesas atendem às prioridades políticas, determinando mais ou menos gastos sociais, seja pela definição do salário mínimo, pelo nível de gastos em saúde ou pela criação de novos programas e ações. Mas, de 2005 a 2016, apenas no último ano não houve supera- 
vit (ASSOCIAÇÃO NACIONAL DOS AUDITORES-FISCAIS DA RECEITA FEDERAL DO BRASIL, 2017, p. 53)."

Entretanto, para justificar a alegação de que existe déficit, ao invés de considerar o total das receitas previstas para custear a Seguridade Social, o Governo calcula as despesas e receitas da Previdência Social como se fosse algo totalmente separado. Assim, fica claro que a razões da reforma não se prendem, necessariamente, à falta de recursos para o custeio dos benefícios

\section{A REFORMA DA PREVIDÊNCIA, A QUEM BENEFICIA?}

Mesmo pagando a conta, como contribuinte, a população brasileira ainda não percebeu que o Governo não faz favores, é seu papel precípuo promover a justiça social por meio de programas e "benefícios" financiados pela própria população. Ser cidadão é, antes de tudo, ter consciência de que tem direito a ter direitos. A aposentadoria é um desses diretos assegurados na Carta Magna, e, portanto, deve ser observado com lupa a proposição de alterações no rol de diretos constitucionais.

O discurso político, disfarçado de econômico e social, patrocinado pelo Governo ao defender a Reforma da Previdência ganha ares de verdade ao ser ratificado pelos meios de comunicação do País. A propaganda promovida pelo Governo e apoiada pelos conglomerados midiáticos quer nos fazer crer que o deficit fiscal da Previdência é culpa do trabalhador, que quer se aposentar antes do tempo, sem fazer jus a esse direto. Pela nova proposta, é preciso trabalhar mais tempo e receber um benefício menor. Em momento algum se cogita a cobrança dos maiores devedores da Previdência Social, megaempresas e bancos, conforme atesta a ProcuradoriaGeral da Fazenda Nacional, responsável pela cobrança dessas dívidas.

O discurso da Reforma da Previdência Social ignora os $\mathrm{R} \$ 426$ biIhões que não são repassados pelas empresas ao INSS. O valor da dívida equivale a três vezes o chamado deficit da Previdência em 2016.

"Os devedores da Previdência Social acumulam uma dívida de $R \$ 426,07$ bilhões, quase três vezes o atual déficit do setor, que foi cerca de $R \$ 149$,7 bilhões no ano passado. Na lista, que tem mais de 500 nomes, aparecem empresas públicas, privadas, fundações, governos estaduais e prefeituras que devem ao Regime Geral da Previdência Social. (LEÓN, 2017)." 
Esta informação, obviamente, não tem a divulgação necessária, pois colocaria abaixo o maior argumento dos que defendem a Reforma da Previdência, projeto em análise na Câmara dos Deputados. Conforme atesta a Associação Nacional dos Auditores Fiscais da Receita Federal e centrais sindicais, é imperativo que haja mudanças na forma de arrecadação e cobrança de débitos previdenciários:

"É preciso fazer primeiro ajustes no lado das fontes de financiamento. Ou seja, cobrar essa dívida que é dinheiro sagrado de aposentados e pensionistas e foi ao longo do tempo acumulada, gerando quase de $\mathrm{R} \$ 500$ bilhões de débitos inscritos, fora o que está na fase administrativa. O índice de recuperação é pequeno e lento, temos que criar métodos mais ágeis de recuperação desses recursos. (LEÓN, 2017)."

Se realmente há um déficit na Previdência, por que não se cobra das grandes empresas as dívidas acumuladas? Fica claro que uma reforma que protege os mais ricos em função da espoliação dos mais pobres é uma forma de promover a justiça social às avessas. O reflexo de tal raciocínio pernicioso e excludente talvez explique a gritante desigualdade na distribuição de renda no Brasil, estampada em todas as manchetes dos jornais (O 1\% MAIS..., 2017).

Como é possível buscar um equilíbrio social, de modo que todas as pessoas que compõem a sociedade tenham os mesmos direitos, se as forças políticas e econômicas (governos e empresas) estão mancomunadas para transformar a legislação que garantia direitos fundamentais em letra morta?

No artigo "Reforma da Previdência: entenda a proposta em 22 pontos", o jornal O Globo apresenta uma série de questões que subsidiariam a necessidade da reforma (REFORMA..., c1996-2018). Nos telejornais, da mesma maneira, há uma unanimidade entre os especialistas convidados a opinar sobre o assunto. Todos declaram a inexorabilidade da Reforma da Previdência.

Este mesmo discurso foi usado para promover a Reforma TrabaIhista, que potencializou a precarização das condições de trabalho, dando ao patrão uma série de prerrogativas antes vedadas. No caso da proposta de Reforma da Previdência busca-se uma fórmula que obrigue o trabalhador a estar empregado depois dos 60 anos, sem garantir que o mercado oferecerá oportunidades de trabalho para pessoas que já não estão no auge da produtividade. 
Entender os discursos veiculados pela mídia exige que não sejamos inocentes, que leiamos nas entrelinhas, que levemos em consideração as intenções que podem subjazer o discurso salvador. Como afirma o pedagogo brasileiro Paulo Freire (1985), no que concerne à vinculação da leitura da palavra à interpretação do mundo, só é possível entender a escrita por meio do mundo concreto; para isto é necessário analisar os discursos que estão por trás destes enunciados, que nunca são gratuitos, mas dirigidos meticulosamente por uma ideologia subjacente. Portanto, o leitor não pode ser ingênuo, precisa fazer uma leitura que leve em conta o texto e o contexto para que possa ser compreendido criticamente. Ler a palavra é ir além do que está escrito.

Nosso país vive uma das mais graves crises políticas de sua história, com um presidente que já enfrentou no Congresso Nacional dois processos de impeachment na mesma legislatura. E até o final do mandato, um novo processo de impeachment pode estar a caminho. Um presidente no exercício do mandato é denunciado pelo crime de corrupção passiva, como parte do inquérito que também investiga se houve obstrução da Justiça e organização criminosa. Este cenário político precisa ser tirado do foco. É uma forma de desviar a atenção para assuntos que pareçam extremamente urgentes e de efeito pirotécnico.

Não podemos nos furtar à reflexão sobre o papel que a mídia vem exercendo sobre a opinião pública, apresentando reportagens sobre a emergência da Reforma da Previdência. A liberdade de imprensa é uma conquista legítima e imprescindível ao regime democrático de direito, é um valor fundamental à realização formal e material da democracia. Entretanto, não se pode aceitar uma imprensa parcial e política e economicamente comprometida, pois a mídia tem um papel influenciador sobre a população e seus reflexos podem ser devastadores, caso opte por alienar a população apresentando apenas um ponto de vista sobre a questão de grande importância como é a reforma da Previdência Social.

Como se sabe, a notícia é um combustível social. É a partir da informação que se estabelecem os diálogos, que se constroem ideias, que se interage com o outro. Este é o papel principal da imprensa: fomentar o debate na sociedade, mostrando diferentes perspectivas de um mesmo assunto.

Uma população verdadeiramente esclarecida deve saber ler a notícia, criticar, dialogar com as informações, não apenas aceitá-la como 
verdade absoluta. A leitura crítica das notícias, baseada em uma leitura da palavra contextualizada, é essencial para a participação livre e esclarecida das pessoas no debate público das ideias políticas. Indubitavelmente, a informação é a maior arma contra a corrupção. A imprensa livre e independente pode ser considerada um quarto poder, responsável por fiscalizar, extraoficialmente, e dar publicidade aos atos do Governo de forma a manter a população informada.

\section{A REAL INTENÇÃO DA REFORMA PELO GOVERNO}

Segundo Wagner, Rambo e Andrade (2017, p. 7), nem todas as receitas que deveriam ser destinadas à Previdência chegam efetivamente aos seus cofres: "Metade do valor que o Governo alega que seria déficit equivale a renúncias fiscais, ou seja, valores que ele mesmo deixa de cobrar para beneficiar determinadas situações ou instituições a empresas".

Desde o ano de 2000, 20\% do valor recolhido a título de contribuições sociais (ou seja, boa parte dos recursos que iam para a Previdência Social) pode ser usado, de forma legal, para pagar outras despesas que não da Seguridade Social (WAGNER; RAMBO; ANDRADE, 2017).

"Em 2016, foi promulgada a EC no 93, que restabeleceu a DRU (Desvinculação de Receitas da União) até 2023. Com ela, $30 \%$ das receitas de contribuições sociais, exceto a previdenciária, deixam de compor o financiamento da Seguridade Social e podem ser gastas em outras áreas a critério do Governo Federal. Também são desvinculados $30 \%$ das receitas de taxas. Apesar de a publicação ocorrer em setembro de 2016, uma cláusula especial de vigência fez com que os efeitos dessa subtração de recursos retroagissem a $1^{\circ}$ de janeiro de 2016 (ASSOCIAÇÃO NACIONAL DOS AUDITORES-FISCAIS DA RECEITA FEDERAL DO BRASIL, 2017, p. 44)."

"A exclusão previdenciária, que hoje já alcança um terço dos trabaIhadores ocupados sem cobertura previdenciária, dentre eles os mais de 10,6 milhões de empregados sem carteira assinada, deve aumentar" (ASSOCIAÇÃO NACIONAL DOS AUDITORES FISCAIS DA RECEITA FEDERAL DO BRASIL, 2017, p. 42), seja pelos efeitos da reforma trabalhista, seja pelos efeitos da própria reforma da previdência. 
Conforme denúncia a ANFIP (2017), "o tratamento privilegiado concedido a fraudadores e sonegadores das contribuições previdenciárias vai permanecer. $\mathrm{E}$, para dar continuidade a esse tratamento, o Governo enviou para o Congresso, em 2017, três programas de parcelamento de dívidas previdenciárias, inclusive um para as contribuições do campo, com altos índices de perdão de juros e multas e com prazos de vinte anos. Como invariavelmente essas medidas viram leis, a sanção governamental convalida o conjunto das benesses" (ASSOCIAÇÃO NACIONAL DOS AUDITORES FISCAIS DA RECEITA FEDERAL DO BRASIL, 2017, p. 42)."

"Em contrapartida, para os segurados, a reforma reserva maiores contribuições, mais exigências e menores benefícios. [...] Para muitos trabalhadores as novas regras exigem condições inalcançáveis. A reforma impõe 25 anos de contribuição (300 contribuiç̧̃es) como requisito mínimo para a aposentadoria. Quase 30\% dos segurados do RGPS possuem menos de seis contribuições em cada ano e precisariam mais de 50 anos de trabalho para completar essa exigência. Do total de trabalhadores segurados, $42 \%$ apresentam nove ou menos contribuições por ano. Esse conjunto possui apenas 4,9 contribuições de média anual. Nessas condições, mantida a mesma frequência contributiva, completar 300 contribuições exige seis décadas no mercado de trabalho. Isto é uma média nacional. Nas pequenas cidades, na periferia das metrópoles, para as muIheres, para os segmentos de menor escolaridade, a exclusão será maior, considerando a dificuldade de inserção no mercado de trabalho. A reforma construirá uma legião dos sem-aposentadorias. $E$, naturalmente, esse fato será um grande incentivo para a informalidade (ASSOCIAÇÃO NACIONAL DOS AUDITORES FISCAIS DA RECEITA FEDERAL DO BRASIL, 2017, p.p. 42-43)."

O relator da CPI da Previdência afirma que o Governo apresentou à população brasileira "dados irreais e contas que não procedem", promovendo "massiva propaganda enganosa e terrorista para mentir e aterrorizar a população" (AGÊNCIA SENADO, 2017a).

"Para que o trabalhador tenha acesso a um benefício equivalente à sua média de contribuições, a reforma exigirá 40 anos de contribuições. Se a exigência de 25 anos (300 contribuições) já é excessiva para a grande maioria dos trabalhadores, 40 anos (480 contribuições) é um escárnio. 
Essa reforma apresenta um total descompasso com a realidade do mercado de trabalho brasileiro.

A reforma, que aumenta o tempo de contribuição dos trabalhadores para 25 anos no mínimo e para 40 anos para a aposentadoria integral, é a mesma que mantém inalterado em cinco anos o tempo de decadência e prescrição das dívidas previdenciárias das empresas.

O incentivo à privatização da cobertura previdenciária é grande. Para os regimes próprios de previdência dos servidores, esse efeito pode ser imediato, pois a reforma acabou com as exigências de que a previdência complementar tenha quer ser feita por entidades fechadas de natureza pública. Planos promovidos por entidades abertas são exatamente os oferecidos pelos bancos e outras entidades financeiras Para o RGPS, as novas exigências e as incertezas promovidas pelas mudanças passam uma percepção de que a saída, para os que podem, está nos planos de previdência privada. Se em janeiro de 2017, os prêmios arrecadados pelos diversos planos privados somaram $R \$ 1,6$ bilhão, em junho do mesmo ano, esse valor já era de $\mathrm{R} \$$ 1,8 bilhão - um aumento de 12\% (ASSOCIAÇÃO NACIONAL DOS AUDITORES FISCAIS DA RECEITA FEDERAL DO BRASIL, 2017, p. 43)."

Assim, os "incentivos" da reforma da Previdência diminuem os efeitos da crise para esse segmento.

A partir dos dados revelados pela ANFIP, o que fica evidente é que as questões relativas à Previdência Social não estão sendo tratadas de forma séria pelo Governo, pois é sabido que existem fatores que exigirão adaptações do sistema previdenciário e que devem ser discutidos pela sociedade como, por exemplo, o aumento da expectativa de vida e o envelhecimento da população.

Entretanto, o que se apresenta agora não é um debate por meio de dados reais, análises aprofundadas da questão, pelo contrário: o Governo resolveu adotar a opção mais simples, que é a de penalizar a classe trabaIhadora aumentando o tempo para a aposentadoria e reduzindo o valor dos benefícios, tudo com o suposto objetivo de corrigir o "rombo" que não é culpa do trabalhador, e, pior, rombo que nem sequer existe.

A reforma proposta só tende a repetir o que tem ocorrido nas sucessivas reformas da Previdência, cujo foco foi de mudar os benefícios para reduzir seu valor e aumentar os requisitos e carências. Em consequência, os prejudicados são sempre aqueles que trabalham e que precisa- 
rão fazer uso do sistema. No entanto, o que poderia ser feito é extinguir a permissão de usar os recursos das contribuições sociais para outros fins; reduzir as renúncias fiscais, cobrando as dívidas e combatendo a corrupção. A Seguridade decorre da Constituição Federal, a garantia da dignidade da pessoa humana é um dos fundamentos da República Federativa do Brasil e é claro que não há dignidade se os benefícios previdenciários não garantirem o sustento daqueles que mais precisam de atendimento.

Então, mesmo que a Previdência fosse realmente deficitária, não parece justo ou razoável pretender diminuir as despesas reduzindo benefícios, especialmente quando não se toma providências para reduzir o maior gasto do orçamento da União, que são as despesas com juros e amortização da dívida pública, que equivalem a quase o dobro do que se gasta com toda a Seguridade Social. Portanto, os dados trazidos só reforçam a necessidade de uma discussão mais aprofundada da matéria, até para fins de estabelecimento das prioridades do Governo como representante da sociedade.

\section{CONSIDERAÇÕES FINAIS}

Por conta da intervenção militar pelo Governo Federal no estado do Rio de Janeiro, a reforma da Previdência não pode nem tramitar no Congresso. Realmente, é um alívio pensar que, pelo menos temporariamente, esta malfadada reforma saiu dos holofotes do Governo e da mídia. Obviamente, a própria intervenção é uma tentativa de manobra política, ainda mais porque 2018 é ano eleitoral, e nenhum parlamentar votaria uma matéria tão controversa, capaz de inviabilizar o partido político ou sua candidatura.

Este desfecho inesperado da proposta de Reforma da Previdência é uma prova cabal do poder imenso de dissuasão do Governo, capaz de enterrar uma proposta tida como de honra para o atual mandatário. Tais reviravoltas são a expressão de um governo acossado tantas vezes pela ganância de poder unilateral, que busca sustentar-se no poder, seja por alianças espúrias com outros partidos, seja pela perniciosa aliança com empresas patrocinadoras de campanhas políticas. As democracias indiretas são frágeis, um grupo partidário chega ao poder e todos os meios podem ser usados para sua perpetuação. 
É imprescindível ir além das palavras, das manchetes dos jornais. Ler o mundo de forma contextualizada, consciente de cada discurso esconde uma intenção não necessariamente declarada. Lutar pelos direitos adquiridos, compreendendo o sentido de liberdade de expressão do pensamento, de crítica ao Governo sem medo de represália, de uma imprensa livre que informa e não deforma.

A Constituição de 1988 assegura o direito à vida, à liberdade de pensamento e expressão, ao trabalho, à saúde, à educação como direitos fundamentais, não é admissível que reformas como a da Previdência, proposta pelo Governo, retire direitos a duras penas adquiridos. Se esses direitos integram dimensão fundamental do ser humano, é dever da Justiça assegurá-los. Negar esta garantia é negar o acesso à Justiça, é rasgar a Constituição e desconsiderar a democracia e a cidadania.

\section{REFERÊNCIAS}

AGÊNCIA SENADO. CPI da Previdência aprova relatório final por unanimidade. Senado Notícias, Brasília, 25 out. 2017a. Disponível em: <https:// www12.senado.leg.br/noticias/materias/2017/10/25/cpi-da-previdencia -aprova-relatorio-final-por-unanimidade>. Acesso em: 06 nov. 2018.

AGÊNCIA SENADO. Veja os principais pontos do relatório da CPI da Previdência. Senado Notícias, Brasília, 24 out. 2017b. Disponível em: < https:// www12.senado.leg.br/noticias/materias/2017/10/24/veja-os-principais -pontos-do-relatorio-da-cpi-da-previdencia>. Acesso em: 06 nov. 2018.

AMARO, M. N.; MENEGUIN, F. B. Previdência social no Brasil: o que foi feito, o que falta fazer. Revista de Informação Legislativa, Brasília, v. 40, n. 157, p. 9-37, jan./mar. 2003. Disponível em:<http://www2.senado.leg.br/ bdsf/handle/id/832>. Acesso em: 06 nov. 2018.

ASSOCIAÇÃO NACIONAL DOS AUDITORES FISCAIS DA RECEITA FEDERAL DO BRASIL. Análise da Seguridade Social 2016. Brasília: ANFIP, 2017. Disponível em: <https://www.anfip.org.br/doc/publicacoes/Documentos_02_08_2017_08_01_57.pdf>. Acesso em: 13 nov. 2018.

BONAVIDES, Paulo. Curso de Direito Constitucional. São Paulo: Malheiros Editores, 2007.

BRASIL. Constituição (1988). Constituição da República Federativa do Brasil. Brasília, DF: Senado Federal,1988. 
CASTOR, B. V. Custo Brasil: muito além dos suspeitos habituais. Revista da FAE, Curitiba, v.2, n.2, p. 1-6, maio/ago., 1999. Disponível em: <https://revistafae.fae.edu/revistafae/article/view/515/409>. Acesso em: 06 nov. 2018.

FREIRE, P. A importância do ato de ler: em três artigos que se completam. São Paulo: Ed. Cortez, 1985.

LEÓN, Lucas Pordeus. Devedores da Previdência respondem por quase três vezes o déficit do setor. Agência Brasil, Brasília, DF, 20 fev. 2017. Economia. Disponível em: <http://agenciabrasil.ebc.com.br/economia/ noticia/2017-02/devedores-da-previdencia-devem-quase-tres-vezes-odeficit-do-setor>. Acesso em: 06 nov. 2018.

MANO, M. K. A Previdência é sustentável, mas seus recursos estão em disputa. \#carta: ideias em tempo real, São Paulo, 24 out. 2016. Disponível em:<https://www.cartacapital.com.br/economia/a-previdencia-e-sustentavel-mas-seus-recursos-estao-em-disputa>. Acesso em: 06 nov. 2018.

O 1\% MAIS rico do Brasil fica com $27 \%$ da renda nacional. Os $10 \%$ mais ricos, com 55\%. \#carta: ideias em tempo real, São Paulo, 14 dez. 2017. Disponível em: <https://www.cartacapital.com.br/economia/o-1-mais-ricodo-brasil-fica-com-27-da-renda-nacional-os-10-mais-ricos-com-55-1>. Acesso em: 06 nov. 2018.

REFORMA da Previdência: entenda a proposta em 22 pontos. O Globo, [s.l.], c1996-2018. Economia. Disponível em: <https://oglobo.globo. com/economia/reforma-da-previdencia-entenda-proposta-em-22-pontos-19744743>. Acesso em: 06 nov. 2018.

SILVA, João Ernesto Aragonés. Curso de direito constitucional positivo. 35. ed., rev. e atual. São Paulo: Malheiros, 2012.

SILVA, Marcela Vitoriano. O princípio da solidariedade intergeracional: um olhar do direito para o futuro. Veredas do Direito, Belo Horizonte, v.8, n.16, p.115-146, jul./dez. 2011. Disponível em: <http://www.domhelder.edu.br / revista/index.php/veredas/article/view/179>. Acesso em: 14 jun. 2016.

VIANNA, João Ernesto Aragonés. Curso de direito previdenciário. $5^{\mathrm{a}}$ ed. São Paulo: Atlas, 2012.

WAGNER, J. L.; RAMBO, L. I.; ANDRADE, V. F. Cartilha crítica da reforma da previdência. Brasília, DF: Wagner Advogados Associados, 2017. Disponível em: <https://www.anfip.org.br/doc/publicacoes/Documentos_20_03_2017_18_29_12.pdf >. Acesso em: 06 nov. 2018. 